\title{
New minister plans for selectivity and flexibility
}

Paris

M. Hubert Curien, newly-appointed minister of research and technology in France, is preparing to make French science policy really work.

For three years, French scientists have enjoyed close attention, encouragement and even cash from a government which saw - and still sees - science as the nation's salvation. But the economic results have been disappointing, and major government programmes in biotechnology and electronics, for example, have been criticized as substantial failures.

Publicly, Curien does not agree. ("It's difficult for a minister to admit failures", he said in his Paris office last week.) But within the ministry, he is making a careful assessment of the "programmes mobilisateurs" set in train by his predecessor, Jean-Pierre Chevènement, in 1982.

Selectivity is the watchword. The trouble with the early dreams was their breadth, all of biotechnology, for example, or all of electronics. But France has only 50 million people and, more tellingly, a history of success in narrow rather than broad technologies such as: nuclear power, space and the high-speed trains. Curien's task must now be to focus the programmes more narrowly.

Curien was previously president of the French space agency (CNES) and of the European Space Agency (ESA), and he recognizes the difficulty. "It is much easier to make good central policy in things like space, where there are few customers and, when you have half-a-dozen programmes, you've covered all the field.'"

Curien says that while the biotechnology programme did not achieve everything, it created a number of small companies and developed a view of what French industry needed to do. So Curien now has to choose. So far, he has picked agriculture and food, where many of the French traditional industries (such as wine and cheese) are both of great importance to the French economy and in very poor contact with French science. This must change "very rapidly" if the industry is to remain competitive.

In electronics, similarly, there must be rationalization and selection, he says. He cites as promising fields software, where France is already strong, robotics ("we've made some advances") and computer hardware where, says Curien, we should expect a new French product in the midrange between a microcomputer and a minicomputer.

French researchers should also find themselves with more computers next year, according to Curien. He claims to have cut the Gordian knot which effectively forbade French laboratories to buy foreign computers while the French industry struggled to catch up. This policy has led to serious under-equipment particularly in nuclear physics groups. But from next year, says Curien, groups will be free to buy computers which are "essential" for their laboratories if they will not be available "in the coming years"' in France.

Curien is also seeking more money for industrial research, both from industry itself and from banks. "There is still a large gap between the [1982] plans and reality." France will have to make a "big effort" to catch up with Japan or even West Germany. In the big companies it is a question of rate; in the small, that they do no research at all. The big companies can be influenced from Paris but Curien says the government encouragement of regional science policy is beginning to have important effects on the smaller enterprises. Curien is also consulting the banks about legal obstacles to raising risk capital. In France, a person once bankrupt is forbidden from ever running a business again.

The minister also plans to raise the political temperature of science again next year (cooler now than in the Chevènement years) by staging a major debate on French research and development in the National Assembly. The topic, ostensibly, will be that of what is to be done in 1985 when Chevènement's 1982 law on the orientation and support of French science comes to the end of its term. "It may be a new law, it may not", says Curien noncommittally. One possible theme is a linkage between the ministry of research and technology and the Administration du Plan, the French ministry that makes long-term " "plans" for France with a considerable degree of independence from the president or prime minister - and a sometimes equal independence from effect.

Another key issue for Curien is the old chestnut of finding jobs for young researchers, or the ageing of the research community. So far France has not met the 4.5 per cent recruitment target of the 1982 law but has kept up a respectable 3 per cent; but even this cannot go on, says Curien. "We cannot solve this problem by creating new jobs every year. We must have a real policy." In 10 years the problem will change as the "recruitment bulge" retires but the bulge comes at different times in different agencies so that retirement and recruitment must be managed.

Curien says that making the scientists civil servants (in a new employment contract to be published soon) "will ease the situation". The point is that the new contract will give researchers "a parachute" - a guarantee of their old jobs back - if they shift into something new (such as industry). Curien hopes this will cause movement and, no doubt, that in the end not too many parachutes will have to be used.

Robert Walgate

\section{Industry favoured by budget}

Aachen

THE budget of the West German Ministry for Research and Technology, which forms 70 per cent of the total government civil research budget, is to be increased by 3 per cent in 1985. This is more than the growth in the national budget ( 1.2 per cent), and reflects the attempt of the government to keep abreast of new technological development.

The distribution of the budget of DM 7,250 million clearly demonstrates the government's intention to promote industrial research efforts. Whereas support for the reactor in Hamm has been reduced by 6.1 per cent, industry will be given increased support, both directly through a 28.5 per cent increase in research subsidies, and indirectly, through a reduction in taxes and financial support for research projects.

Particular encouragement is given to the employment of young scientists by companies with fewer than 3,000 employees and a yearly turnover of less than DM 300 million. Sixty per cent of the salaries of new research staff will be paid for 15 months when these conditions are fulfilled. Exchange of younger scientific personnel from industrial research laboratories to academic laboratories will also be supported to stimulate transfer of information between the sectors.

In particular, the redistributed budget is designed to assist the foundation of more new technology-oriented companies for which an increase of financial support of nearly 150 per cent is foreseen. Directly supported research institutes, which absorb more than one-third of the whole budget, are expecting an increase of 5.3 per cent. Furthermore, Dr Heinz Riesenhuber, the Minister for Research and Technology, stresses the need for adequate research into the consequences of new technological developments. In the face of the effect of pollution on the forests in Germany, efforts are to be made to evaluate a wide range of developments, from the use of methanol as a fuel to the value of the electronics industry in improving the employment market. A 122 per cent increase in funds for such studies is anticipated.
Jurgen Neffe 